\title{
VISÃO PANORÂMICA DA ARTE ESPANHOLA
}

\author{
Dr. Fr. Mansueto Kohnen, O.F.M. \\ Prof. de História das Artes - Rio
}

A arte espanhola é, dentro da comunidade européia, mais única que rara. A polaridade da arte italiana e germânica não $́$ idêntica à polaridade do norte e sul europeus. $O$ conceito "sul" inclui também a Espanha, o conceito "norte" abarca igualmente a arte da Inglaterra e dos Países Baixos.

Porém, todas estas culturas de arte constituem algo absolutamente autóctone. Só caracterizando a arte espanhola, inglêsa e neerlandesa em contraste com a germânica, francesa e italiana e, ao mesmo tempo, reconhecendo as relações entre elas existentes, é que poderemos tornar claro o destino e as possibilidades da Europa.

\section{OS PRINCIPAIS MESTRES DA ESPANHA}

No domínio da escultura destacaram-se principa.mente Alonso Berruguete (ca. 1486-1561), Juan Martinez Montañés (15801649) e Francisco Salcillo (1707-1781).

Entre os pintores anotamos os grandes mestres Francisco de Goya (1746-1828), B. Esteban Murillo (1617-1682), Jusepe de Ribera (1588-1656), Doménico Theotocópuli, denominado "El Greco" (1541-1614), Diego Rodriguez de Silva Velázquez (15991660). Francisco Zubarán (1598-1664) e, afinal, Pablo Picasso. que nasceu em 1881.

A Espanha é uma terra enigmática. Aquêles que a conhecem, evitam afirmações definitivas e perentórias. A alma espanhola não pode ser compreendida de qualquer ângulo parcial. Também a arte desta terra — semelhante à arte inglêsa — nãc consegue abarcar tôda a essência inteira das terras hispânicas. Ela foi sempre, na Espanha, verdadeira arte popular, o que ou- 
tros povos da Europa não podem afirmar de sua arte com esta intensidade comovedora. Poucas vêzes sublinha o acento artesão ou serve exclusivamente a um determinado estado social.

A alma espanhola se expressa ainda em certas formações e formulaçōes de sua língua. Ela possui uma criatividade incessante de imagens, de metáforas e ditos populares, de provérbios regionais, ostentando uma aversão típica contra qualquer formação lexiográfica. Qual é a razão mais profunda desta atitude? A imensidade da fantasia refulgente sobrepuja e vence tudo.

Existem ainda outros fatôres na vida das terras espanholas, fatôres que as caracterizam, mas não as definem cabalmente. Pois, ai vive o humor trágico de um Dom Quichote. E ninguém desconhece os famosos "toreros", o teatro e a dança, expressões típicas espanholas. Cada um destes fatôres constitui uma expressão própria e insubstituível do carácter espanhol.

Eis o contraste mais e'oqüente: podemos ler ou deduzir a essência dos povos italiano, francês e germânico de suas criações arquitetônicas e esculturais, parcialmente até de suas pinturas, porém, a arte espanhola manifesta apenas uma faceta, um aspecto, uma expressão, e uma parte de sua alma quase incompreensivel. E esta UMA expressão é, contudo, particularmente importante $e$ intensa.

Que poderia ter contribuido para êste fato? Cremos que as paisagens e o meio-ambiente exercem enorme influência sôbre a arte e a cultura de todo e qualquer povo. $E$ as paisagens espanholas conhecem contrastes enormes e violentos. Existe $c$ clima brutal das altas montanhas e a dureza amarga do planalto castelhano como ainda existem a plenitude sulista e a sêca sertaneja. Assim, também na arte espanhola há contrastes violentos. Ela é concebivel quase só na polaridade de frieza ou brasa. de melancolia ou êxtase, de dureza hibernal ou fulgor estival. Corresponde inteiramente ao caráter espanhol a muralha fria do Escorial e a graciosidade sonhadora do Alhambra (dos séculos XIII-XIV). Correspondem-lhe ainda as vestimentas pretas dos grandes nos quadros de Velázquez, a proximidade da terra e, ao mesmo tempo, a visão mística de "El Greco" no entêrro do conde de Orgaz, como lhe correspondem o êxtase incorpóreo dos retratos 
dourados da Imaculada (Madrid, Prado) da autoria de Murillo. as fachadas ricamente adornadas de catedrais e a originalidade simples de antiquíssimas, pequenas e, contudo, fortes igrejas aldeãs.

Convém salientar outra propriedade da arte espanhola. Pode-se afirmar que da arte espanhola ainda faz parte, em geral, - povo espanhol o que não podemos dizer com a mesma intensidade de outros povos. O povo espanhol ainda considera as esculturas e pinturas religiosas - a arte espanhola nasce, de preferência, do acento religioso! - fôrças que sôbre êle agem, atuam e permanecem. E' difícil encontrar outra terra, onde a arte não seja considerada sob o aspecto estético. Isto acontece na Espanha. $E$, contudo, há poucas terras ou paises, em que determinadas estátuas de Cristo ou da Virgem são tão intensamente amadas e veneradas como em terras hispânicas. E' significativo, que dêste amor e desta veneração participam tôdas as camadas do povo espanhol. A fama destas estátuas é sem par. A arte espanhola responde às perguntas e aos problemas de homens vivos. $A$ obra artística ainda exerce sôbre o povo um poder mágico e vivificador.

Muitos povos e várias raças perpassaram as plagas hispânicas. Os árabes a dominaram quase 800 anos. Porém, o povo espanhol e sua arte formam UMA entidade, se bem que a unidade interior não lhe foi dada pelo destino qual presente ditoso. So the foi presenteado uma luta consciente.

Desde os primórdios existem, na Espanha, dois fatores essenciais: orgulho de raça e de fé. Explica-se, desta maneira, que os elementos não autóctones não conseguiram vingar autônomamente. mas êles foram português (nota-se em sua arte, que êl’ se distancia do extático), mas êle tornou-se, ao mesmo tempo, um dos plasmadores decisivos da "Hispanidad" através de seu realismo inexorável e abismal. Theotocópuli — "El Greco" apesar de sua origem grega, amalgama em sua arte a herança bizantina e o elemento formal da pintura veneziana de maneira abrasadora com o tipicamente espanhol, como documenta o entêrro do conde de Orgaz (1586, Toledo. Santo Tomé). E no fim da Idade Média trabalharam muitos artistas nórdicos em terras da 
Espanha. Sua fantasia nórdica se une com as produções da arte árabe, formando, contudo, um todo indubitàvelmente espanhol.

Os próprios testemunhos da cultura árabe em Granada, Sevilha e Córdoba - apesar da veemência das discussões religiosas e políticas entre conquistadores e conquistados - são e formam simplesmente uma parte importante da essência espanhola. Ja. mais chegaram a ser corpos estranhos. Ante as montanhas su berbas e cobertas de neve da Sierra Nevada ergue-se, qual fortaleza, o Alhambra, moradia dos árabes guerreiros, provenientes da Africa. Porém no interior aparece a arquitetura leve e quase im. provisada: abóbadas semelhantes a concretizações calcáreas, ornamentos infinitamente progressivos, poços e chafarizes, flôres e laranjais, versos e inscrições de profundo sentido e quase orna-. mentais nas paredes, que relacionam o fulgor dos sentidos com Deus, que é UM e o Único. A Espanha das épocas subsequientes não deixa de manifestar êste contrato entre guerra e sonho, entre realidade e fantasia, para criar um todo de todos os fatôres terrestres e temporais na parábola, na comparação e na sublimaçãc.

Como poderemos talvez reconhecer a unidade interior da arte espanhola? Talvez seja possivel reconhecer sua unidade interior por aquilo que falta e por aquilo que ela recusa ou rejeita.

FALTA, na arte das terras hispânicas, quase por completo, : grande arquitetura românica. Quais seriam as razões? Muitas vî. zes, motivos exteriores, por exemplo, guerras e crises econômicas a impediram. Porém, a razão psicológica mais acertada nos parece ser esta: a arquitetura maciça do estilo romano talvez possa párecer demasiado equilibrada a êste povo dos extremos e das polaridades. E significativo, em todo caso, que o poderoso cerne da catedral de Santiago sofreu uma inundação de chafarizes e orna. mentos.

RECUSA e REJEITA a arte espanhola, quase sempre, o elemento sistemático e a clareza transparente da gótica francesa. Houve apenas um curto período de influência. A Espanha forma suas próprias grandes salas góticas. Elas são amplas. Desconhecem orientação matemática. São salas sonhadoras como as salas de colunas das mesquitas árabes. A construção é encoberta por riquíssimo ornamento. Dissolve, enfim, a abóbada num ponto agudo da 
lanterna. Por fim, a arte espanhola rejeita ainda, com clarividência, a renascença italiana. Que lhe pode significar esta arte concentrada e comedida?

Não predominam, na arte criada por espanhóis, os motivos profanos. Notamos uma certa seleção de motivos. A arte hispânica parece menosprezar, na escultura, o túmulo e o "portrait", como não dá destaque, na pintura, ao "genre" e à paisagem. A mitologia, preferida na arte italiana, não tem importância pará ela. Ainda mais: o corpo como tal quase nunca se torna objeto da pintura. Por isso, Jedlicka acerta ao afirmar: "Der Kruzifixus ist fast die einzige nackte maennliche Gestalt der spanischen Malerei." (Cfr. Spanische Malerei. Berlim 1941, VII). — Só duas obras representam até o século $X I X$ o nu feminino para cultiválo: a "Vênus", de Velázquez (Londres), e a "Maja" de Goya (Madrid).

Indagando pelo tema básico da arte espanhola, qual seria o predominante? - Cremos ser o tema básico na arte da Espanha o seguinte: o homem, a criatura humana, atirada na decisāo religiosa. Este tema vive, nesta arte, com uma passionalidade tremenda. Impulsionando e impulsionada aos extremos - conseguindo pouquissimas vêzes a moderação - ela vê a criatura humana qual ser irrequieto, sacudido pela falta de quietude, empurrado para o misterioso e obscuro, ou ainda elevado e enlevado por uma leveza sonhadora. Para expressar o feio, o vil, o gran. de e o duro com inexorabilidade nua e crua, a arte espanhola se aprofunda com uma quase loucura na realidade e no realismo. Ela é simples e puramente a arte do êxtase! E aí experimenta as mais variadas formas de êxtases: - há os êxtases de fascinação mistica, e quem não recorda os grandes corifeus da mística espanhola, como sejam joão da Cruz, Teresa d'Ávila e Pedro d'Alcântara? - Há os èxtases do realismo vivido - e quem não lembra o São Pedro da cena de Cristo no horto das Oliveiras. da autoria de Zarcillo? - Há, enfim, os êxtases do demoníaco - "4 quem não conhece o pavor metafísico da seqüência "Disparates". como Goya o gravou?

A arte espanhola sente-se atraida particularmente pelos mistérios do Cristianismo. Sua Fé torna-se brasa febril. E' sintomático que, entre todos os povos europeus. o espanhol representa 
mais vêzes e de maneira magistral a Imaculada Conceição. Imortal é a representação de Murillo (Madrid, Prado).

Esta arte dos artistas espanhóis é riquíssima em representações de santos extasiados. El Greco representa, por exemplo, 64 vêzes o êxtase de São Francisco de Assis. E El Greco descreve nestes quadros, com a mesma exatidão, a realidade terrestre como, simultâneamente, o afastamento dela na embriaguez do Amor Divino. Pois, El Creco é o mestre da observação, que não ignora a mais fina renda em seus mínimos detalhes ou a menor faísca de luz num colar ou numa jóia. Sua arte é como um símbolo da arte espanhola, que se vincula à terra e, ao mesmo tempo, dela foge. $E$ a arte que capta tôdas as impressões, todos os scfrimentos e que, contudo, sempre se abre ao sôbre-sensivel.

Este entrosamento de unção religiosa e exatíssima observação da realidade caracteriza sobretudo as grandiosas figuras e estátuas que se conduzem nas tradicionais procissões da Semana Santa. Estas figuras revestem-se de cabelos e vestes artificiais, ostentam fisionomias de côres naturais e lágrimas de cêra. O homem do povo espanhol vive ante estas figuras como co-autor e co-sofredor. Elas fazem parte de seu espaço e de seu meio-ambiente temporal. Vivem dentro da SUA época atual e como que presentes neste instante. Não intenciona a distância estética, pe.lo contrário: o representado (objeto ou personalidade) deve ser realmente experimentado e deve entrar na realidade dos presentes

O realismo espanhol avança até o fundo mais enigmático da vida. Todos os povos europeus pintam a loucura do ser espiritual denominado homem. Porém, ninguém a pintou de maneira tão pavorosa como o fizeram Velázquez e Goya, respectivamente em "A criança de Vallecas" (ca. 1656, Madrid, Prado) e a "Rainha Maria Luísa da Espanha" (München, Museu do Estado Bávaro). Representam inexcedivelmente a fealdade e a demência, a astúcia e a ganância vil.

A arte espanhola retorna também, reiteradas vêzes, ao tema da decadência da vida, ou sejam: a velhice, a dor e a morte. Valdés Leal descreve, na igreja Caridad de Sevilla, em dois famosos quadros, a dissolução da criatura humana: a podridão, a corrupção progressiva, os esqueletos e os ossos dispersos. - Outros te- 
mas preferidos da arte espanhola constituem a Paixāo de Cristc. - martírio dos santos e suas tentaçōes, descrevendo, com grande rea'ismo, a dor e o sangue. o poder súbito dos instintos desenfreados ou a agonia nos lábios azulados e no olhar estarrecido $\epsilon$. aguado.

Após Goya ter evocado inúmeras vêzes todos os horrores da morte - mormente nas duas grandes seqüencias, que parecen: duas enciclopédias do pavor: os "Disparates" - o velho mestre surdo e solitário conjura ainda uma vez nos quadros de sua casa de recreio, ante as portas de Madrid, todo o pavor demoniaco que perpassa as vidas ou que de vez em quando horrivelment : irrompe. Este demonismo - um pesadelo, do qual a arte italiana sempre fugiu, como fugiu do elementar, da dor, da polaridade. entre o bem e o mal! - confere às fôrças telúricas enorme poder sôbre todos os sêres. Emergem figuras, sombras e fantasmas, parecendo corporificaçōes de concupiscência louca e de vontade cega de assassinar e liquidar. Apaga-se aparentemente a livre personalidade espiritual, formando ela apenas uma massa bôba e animalizada. Coya (no auto-retrato. criado por volta de 1819, Madrid. Prado), um dos grandes pintores da humanidade, êle próprio só paixão e melancolia, descobriu e manifestou a negridão psiquica qual proto-fôrça cósmica.

E não é significativo que na atual arte européia surge justamente um espanhol, que realiza a extrema polaridade entre cultc de beleza e de caos. entre harmonia clássica, no retrato de Olga Koklova, sua espôsa, e dissonância berrante, no retrato intitulado "Mulher" (1918. Coleção Chrysler)? Seu nome é Pablo Picasso. Uma das formas principais de sua atividade, que surge de quando em vez em diversos períodos de sua vida, é a delicadeza e - elan resignnado da linha. Porém, despreza, em outras criações. tôdas as estruturas orgânicas dos sêres. Acumula cruelmente fisionomia e figura de fragmentos cúbicos e deformados, mistura os ângulos de visão (profil e frontal) numa mescla detestável até que destruiu numa confusão anárquica tôda a nobra ordem do semblante humano. Diante de tais retratos pode-se imaginar, como satã inão Deus) poderia ter criado a vida humzna. O auto-testemunho de Picasso (cfr. "Le Figaro", 1951) è por demais cruel e sarcástico (e talvez inverídico) para aqui ser 
reproduzido, quando se retrata, êle próprio nestas criações absurdas, qual "amuseur publique". O motivo destas criações de Picasso não está apenas fundamentado em seu temperamento pessoal ou na insegurança existencialista de nossos dias. Co-existem também aqui os contrastes da essência espanhola, que se espelha num artista espanhol da atualidade. Walter Erben cita em "Picasso und die Schwermut" uma palavra de Ortega y Gas. set, que considera a vida, para o espanhol, um distanciar-se: "Talvez seja injusto esperar do espanhol outra coisa a não ser a extraordinária". - Não há outro pintor moderno sôbre o qual se tenha escrito tanto. Alfred $\mathrm{H}$. Barr enumera em "Picasso" (N. York, 1946) 500 títulos de escritos, entre estas 46 monografias. sôbre o pintor espanhol.

Todos os fatôres até agora considerados fazem parte da essência da arte espanhola. E a Europa the deve gratidāo. Por quê? Ela reconheceu (e representou) o ser humano em tôda a sua precariedade. Diz-lhe, que vive num rochedo perigoso.

A realidade apenas temporal tornou-se, para a arte espanhola, como que transparente. $E^{\prime}$ uma realidade ardentemente amada e, todavia, cheia de indizível melancolia. Ela mostra a criatura humana no foco e no âmago das fôrças, que pedem e exigem uma decisão: entre o bem ou o mal, entre Deus ou o demônio. O espanhol lutou em sua grandiosa e trágica História, viveu longe das existências burguesas e distanciado também da vida bucólica. Ele se viu atirado numa situação, que pede decisões - viveu e lutou nobre e valentemente, cheio de melancolia e de fé ardente. Assim é sua Arte, também!

\section{BIBLIOGRAFIA:}

AZCÁRATE: Monumentos españoles. Vols. 5. 1953.

BEVAN: Historia de la arquitectura española. 1950.

WOELFFLIN: Conceptos fundamentales en la historia del arte. 1952.

BARR: Picasso. 1946.

LÜTZELER: Die Kunst der Völker. 1940. — Idem: Führer zur Kunst. 1940. SUBIAS: El arte popular en España. 1948.

SANCHEZ CAMARCO: La muerte $y$ la pintura española. 1954.

JEDLICKA: Spanische Malerei. 1941.

ENCINA: Retablo de la pintura moderna. De Goya a Picasso. 1953. 